\title{
Nutritional profile of the Portuguese cabbage (Brassica oleracea $L$ var. costata) and its relationship with the elemental soil analysis
}

\author{
Maria Fernanda Pessoa ${ }^{1 *}$, Paula Scotti-Campos ${ }^{1,2}$, Isabel Pais ${ }^{2}$, Ana Feteiro ${ }^{1,3}$, Daniela Canuto ${ }^{1,3}$, \\ Manuela Simões ${ }^{1}$, João Pelica', Inês Pataco', Vânia Ribeiro ${ }^{1,3}$, Fernando Henrique Reboredo', \\ José Cochicho Ramalho',4, Fernando Cebola Lidon'
}

${ }^{1}$ GeoBioTec, Departamento de Ciências da Terra, Faculdade de Ciências e Tecnologia, Universidade Nova de Lisboa, Quinta da Torre, Caparica, ${ }^{2}$ Unidade Estratégica de Investigação e Serviços de Biotecnologia e Recursos Genéticos, Instituto Nacional de Investigação Agrária e Veterinária, I.P. (INIAV), Av. República, Quinta do Marquês, Oeiras, Portugal, ${ }^{3}$ Escola Superior de Saúde de Leiria, Instituto Politécnico de Leiria, Campus 2 - Morro do Lena, Alto do Vieiro - Apartado 4137, 2411-901 Leiria, Portugal, ${ }^{4}$ Grupo Interações Planta-Ambiente \& Biodiversidade (Plant Stress \& Biodiversity), Linking Landscape, Environment, Agriculture and Food LEAF), Dept. Recursos Naturais, Ambiente e Território (DRAT), Instituto Superior de Agronomia (ISA), Universidade de Lisboa (ULisboa), Av. República, Quinta do Marquês, Oeiras, Portugal

\section{A B S T R A C T}

\begin{abstract}
The economic and financial crisis has increased the number of urban horticulture on lands close to present or past industrial areas. "Tronchuda" or the Portuguese cabbage (Brassica oleraceae L var. costata DC) was studied because of its importance in Portuguese diet. It belongs to a number of economically significant horticultural crops (Brassica species), which are also known to be nutritionally well-balanced vegetables. "Tronchuda" produced in urban horticultures from 4 regions of mainland Portugal was studied for its nutritional profile along with elemental soil analysis of each sampling site. This study revealed significant interactions between essential elements in soil and plant leaves - the edible part of the plant for human nutrition. In general, these organs contained poor concentrations of Fe and $\mathrm{Si}$, while $\mathrm{Mn}$ is absent, regardless of the sampling sites. Conversely, Ca levels were abundant with values ranging between $3.3 \%$ and $3.9 \%$. Soils from CAP showed a soil nutrient exhaustion of $\mathrm{Fe}, \mathrm{Mn}$ and $\mathrm{Mo}$, although the highest protein and sucrose contents in the leaves was observed in plants growing in those soils. Protein, lipids and carbohydrates concentrations differed according to sampling site, reflecting different production practices.
\end{abstract}

Keywords: Brassica oleracea; Elemental analysis; Nutritional profile; Portugal; Soil

\section{INTRODUCTION}

Portuguese cabbage, also known as "Tronchuda" or "Penca" belongs to the Cruciferous family (Brassicaceae), which includes a variety of economically significant horticultural crops (Sousa et al., 2008) all over the world, such as several Brassica species including kale (Brassica oleracea L. var. acephala DC), cauliflower (Brassica oleracea L. var. botrytis) (port: couve-flor), cabbage (Brassica oleracea) (port: couve Portuguesa, couve galega), rape (Brassica napus L. var. napus) (port: nabo, grelos) and red cabbage (Brassica oleracea L. var. capitata f. rubra) (port: couve-roxa). "Tronchuda" is native of the Mediterranean region and southwestern Europe, extending northward to southern
England (Vaughan and Geissler, 1997). Since it is tolerant to cold winters, maritime exposure (Ferreres et al., 2007), as well as to hot summers, it become an important crop to Portuguese diet and agricultural systems. In fact, "Tronchuda" cabbage is one of the most consumed vegetables in Portugal (OMAIAA, 2011) all over the year, being a common-side dish in Portuguese cuisine. That is the case of "Caldo verde", a popular soup in which finely chopped leaves are the main ingredient, joint with salami slices; in Christmas Eve dinner it is an important ingredient eaten joined with boiled codfish, potatoes and eggs. This species is also part of the Mediterranean diet, which is now under UNESCO classification as immaterial heritage.

\footnotetext{
*Corresponding author:

Maria Fernanda Pessoa, GeoBioTec, Departamento de Ciências da Terra, Faculdade de Ciências e Tecnologia, Universidade Nova de Lisboa, Quinta da Torre, Caparica. E-mail: mfgp@fct.unl.pt
} 
Nowadays, food is looked not only for maintaining body requirements for basic life, but also for health promotion and disease prevention due to other bioactive compounds. Brassicaceae plants are considered to be a good source of bioactive phytochemicals, becoming a research model in plant science, due to the importance of their primary and secondary metabolites (Jahangir et al., 2009). There are some studies related with the benefic effects of Portuguese cabbage leaves (INSA, 2007; Sousa et al., 2008; Batista et al., 2011) and its sprouts (Vale et al. 2015a, b), constituting an important source of aliphatic glucosinolates (GLs), sulphur-containing secondary metabolites related to the pungent flavor and odor of Brassica vegetables. As far as we know, no work has been done concerning site production and Brassica composition. Previous studies showed that "Tronchuda" cabbage reveal high levels of moisture, proteins, fat, energy, $\beta$-carotene and vitamin $C$. Furthermore, this cabbage showed antioxidant potential against various oxidative species in cell free systems (Ferreres et al., 2006; Vrchovská et al., 2006), even at low extract concentrations (Sousa et al., 2009). Brassica oleracea is also reported to have apparent cancer and cardiovascular disease-preventing properties, for which glucosinolates, phenolics and related analogs appear to contribute (Ayaz et al., 2008). Moreover, the renew interest and the revival of popular food, also in many gastronomic menus and national gourmet events, has contributed to revitalize their use and consumption and to increase the prices, causing a growing interest of farmers (Batista et al., 2011).

Considering the above mentioned issues, this work aimed to: a) characterize nutrient composition of this plant and to study a likely relationship between soil and plant uptake, with emphasis on the leaves (which constitute the edible fraction) particularly in what concerns micro and macronutrients; b) analyze the nutritional profile of this plant taking into account the site of production, particularly focused in leaf protein, lipids and carbohydrate contents.

\section{MATERIALS AND METHODS}

\section{Field sampling}

"Tronchuda" cabbage (Brassica oleracea L. var. costata DC), and soil samples nearby roots (0 to $10 \mathrm{~cm}$ depth) were collected in March 2015 in four sites of Portugal: Porto de Mós (PM), Rio Maior (RM), Monforte (MONF) and Costa da Caparica (CAP) (Fig. 1), reflecting different production and environmental conditions. PM site is located in the Parque Natural das Serras de Aire e Candeeiros (PNSAC), a natural protected area. CAP site is located in another Portuguese protected area (Paisagem Protegida da Arriba Fóssil), which harbors an important number of urban farms with an intensive production of vegetables intended for commercial market supply. RM and MONF sites are not under any protection law. Plants from PM, RM, and MONF sites were collected from family yards, largely for their own consumption.

After harvesting, the vegetal samples of three distinct individuals and soil samples were immediately transported to the laboratory, where plants were washed with tap water and cleaned with soft paper. Roots, stem and leaves of each plant were separated and dried at $60^{\circ} \mathrm{C}$ until constant weight, finely powdered with a mill, mixed and stored in a desiccator, in the dark for mineral analysis. For other components (protein, sugars and lipid), biological samples were stored in a freezer at $-80^{\circ} \mathrm{C}$ until analysis. Soil samples were dried at $65^{\circ} \mathrm{C}$ in an oven until constant weight was reached. Then, they were sieved through a $2.0 \mathrm{~mm}$ sieve to remove stones, coarse materials and other debris.

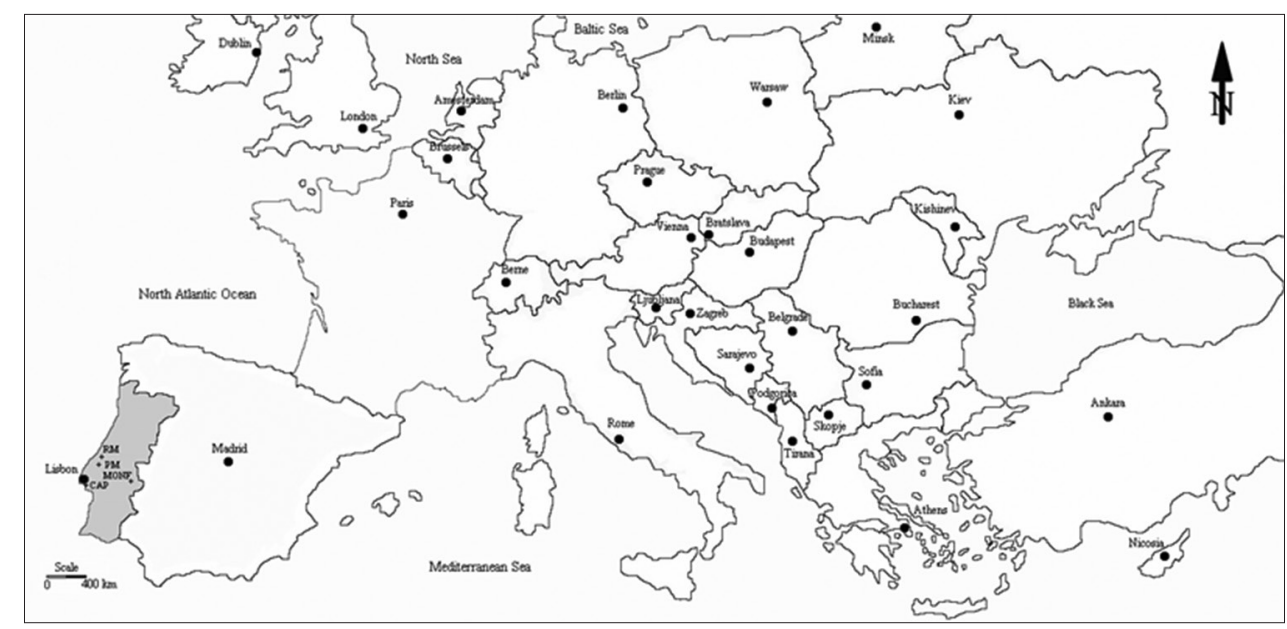

Fig 1. Map of Mainland Portugal in Europe, showing sampling locations: PM (Porto de Mós), RM (Rio Maior), MONF (Monforte), CAP (Caparica). 


\section{Plant and soil elemental analysis}

The elemental composition of soil, roots, stems and leaves, collected from four different sampling points was performed by using a X-ray Analyzer (Thermo Scientific, Niton model XL3t 950 He GOLDD+, USA), under Helium atmosphere. For this, each powdered sample was analyzed, applying the maximum measurement time: 360 seconds. Each plant/soil was analyzed in triplicate.

The Bioaccumulation Factor (BAF) determines the ability of a plant to uptake an element from soils was calculated with the following formula: $\mathrm{BAF}_{\text {root }}=\mathrm{C}_{\text {root }} / \mathrm{C}_{\text {soil }}$; where $\mathrm{C}_{\text {root }}$ and $\mathrm{C}_{\text {soil }}$ represent the metal concentrations in the roots and soil, respectively. The Translocation Factor (TF) is the ratio obtained from heavy metal concentrations in the leaves and roots according to the expression: $\mathrm{TF}=\mathrm{C}_{\text {leaf }} / \mathrm{C}_{\text {root }}$.

\section{Soil pH}

Soil $\mathrm{pH}$ was determined using a portable potentiometer $24 \mathrm{~h}$ after introducing wet soil $(20 \mathrm{~g})$ in $50 \mathrm{ml}$ of distilled water.

\section{Total soluble protein, soluble sugars and lipids}

Leaf samples of ca. $2 \mathrm{~g} \mathrm{FW}$ were homogenized in $20 \mathrm{ml}$ cold deionized water and centrifuged $\left(12000 \mathrm{~g}, 5 \mathrm{~min}, 4^{\circ} \mathrm{C}\right)$ according to the method of Medlicott and Thompson (1985) slightly modified. The supernatant obtained by aqueous extraction was collected and used for total soluble protein and soluble sugar analysis. Protein quantification was performed by copper biuret method according to Gornall et al. (1949), using a Shimadzu UV-160 spectrophotometer (Japan).

Soluble sugars (sucrose, glucose, fructose, raffinose) were analyzed injecting supernatant aliquots $(40 \mu \mathrm{l})$ in a HPLC using a system equipped with a refractive index detector (Model 2414, Waters, USA). Samples Sugars separation was performed using a Sugar-Pak 1 column $(300 \times 6.5 \mathrm{~mm}$, Waters), as described in Ramalho et al. (2014). Standard curves were used for the quantification of each sugar.
Total leaf lipids were extracted from $1 \mathrm{~g} \mathrm{FW}$ frozen leaf samples with a mixture of chloroform/methanol/water $(1 / 1 / 1 ; \mathrm{v} / \mathrm{v} / \mathrm{v})$, according to Allen et al. (1966). For fatty acid (FA) analysis, aliquots of total lipids extracts were saponified and methylated with $\mathrm{BF}_{3}$-methanol, using heptadecanoic acid (C17:0) as internal standard. The fatty acid methyl esters were analysed by Gas Chromatography, using a GC-FID equipment (CP-3380, Varian, CA, USA). Separation was carried out on a DBWax capillary column $(0.25 \mathrm{~mm}$ i.d. x $30 \mathrm{~m}, 0.25 \mu \mathrm{m}$, $\mathrm{J} \&$ W Scientific), as described by Scotti-Campos et al. (2014). FAs were identified by comparison with known standards (Sigma, USA). Total fatty acids corresponded to the sum of individual FAs: linolenic (C18:3), linoleic (C18:2), oleic (C18:1), stearic (C18:0), hexadecatrienoic (C16:3), hexadecenoic or palmitoleic (C16:1) and palmitic (C16:0) acids.

\section{Statistical analysis}

An analysis of variance (one and two way ANOVA) was performed for data interpretation, using the Excel plugin package for Windows, to show eventual interactions between the variables selected and/or site sampled. Tukey's significant difference test was used to compare means using the least significant difference (LSD) at 95\% confidence level.

\section{RESULTS AND DISCUSSION}

\section{Soil}

The soil elemental composition and $\mathrm{pH}$ values (Table 1) showed differences related to the sampling sites. Silicon (Si) was the most abundant element in the soils, followed by aluminum $(\mathrm{Al})$, calcium $(\mathrm{Ca})$, iron $(\mathrm{Fe})$ and phosphorus $(\mathrm{P})$. Concerning macronutrients (Ca, $\mathrm{P}$ and $\mathrm{K}$ ) concentrations, Ca showed the highest values generally, followed by $\mathrm{K}$ and P. Micronutrients (Fe, Mo and $\mathrm{Mn}$ ) showed significant differences related to the sampling sites: A particular enrichment in Fe in MONF soils was noted. Conversely,

Table 1: Elemental soil composition $\left(\mathrm{mg} \cdot \mathrm{kg}^{-1}\right)$ of each sampling point

\begin{tabular}{lcccc}
\hline pH/Mineral & \multicolumn{4}{c}{ Site } \\
\cline { 2 - 5 } & CAP & PM & RM & MONF \\
\hline $\mathrm{pH}$ & 8.0 & 8.2 & 7.7 & 8.0 \\
$\mathrm{Ca}$ & $26201.0 \pm 225.5 \mathrm{a}$ & $14396.3 \pm 167.7 \mathrm{~b}$ & $26437.8 \pm 217.3 \mathrm{a}$ & $4459.8 \pm 61.1 \mathrm{c}$ \\
$\mathrm{K}$ & $12158.0 \pm 104.3 \mathrm{~b}$ & $10851.0 \pm 105.7 \mathrm{c}$ & $4792.0 \pm 55.4 \mathrm{~d}$ & $19133.7 \pm 174.7 \mathrm{a}$ \\
$\mathrm{P}$ & $2420.9 \pm 114.5 \mathrm{~b}$ & $1801.6 \pm 103.3 \mathrm{c}$ & $2869.6 \pm 109.6 \mathrm{a}$ & $1679.3 \pm 98.6 \mathrm{c}$ \\
$\mathrm{Fe}$ & $4208.5 \pm 44.9 \mathrm{~d}$ & $19259.6 \pm 123.1 \mathrm{~b}$ & $6538.5 \pm 59.9 \mathrm{c}$ & $34235.2 \pm 169.4 \mathrm{a}$ \\
$\mathrm{S}$ & $1837.3 \pm 45.1 \mathrm{~b}$ & $447.7 \pm 36.4 \mathrm{c}$ & $2053.6 \pm 49.4 \mathrm{a}$ & $433.7 \pm 36.3 \mathrm{c}$ \\
$\mathrm{Mo}$ & $2.2 \pm 1.7 \mathrm{a}$ & $2.4 \pm 1.7 \mathrm{a}$ & $3.0 \pm 1.2 \mathrm{a}$ & $3.9 \pm 1.4 \mathrm{a}$ \\
$\mathrm{Mn}$ & $58.7 \pm 17.9 \mathrm{~d}$ & $286.9 \pm 23.5 \mathrm{~b}$ & $161.8 \pm 20.7 \mathrm{c}$ & $560.3 \pm 29.5 \mathrm{a}$ \\
$\mathrm{Si}$ & $212901.4 \pm 743.5 \mathrm{a}$ & $176870.4 \pm 689.8 \mathrm{~b}$ & $165922.6 \pm 665.5 \mathrm{c}$ & $155677.0 \pm 643.2 \mathrm{~d}$ \\
$\mathrm{Al}$ & $17671.9 \pm 362.7 \mathrm{c}$ & $25884.1 \pm 423.3 \mathrm{~b}$ & $13411.2 \pm 327.2 \mathrm{~d}$ & $35883.2 \pm 515.5 \mathrm{a}$ \\
\hline
\end{tabular}

CAP: Costa da Caparica, PM: Porto de Mós, RM: Rio Maior, MONF: Monforte. Different letters ( $a, b, c, d)$ correspond to significant differences between sites; n.d.: Not detected. (Mean \pm S.deviation; $n=3$ ) 
soils from CAP showed the lowest concentrations of Fe, Mn and Mo which may well be related with soil exhaustion due to the continuous crop cultivation throughout decades. The levels of Mo in the soils are not significant different at the 0.05 significance level $(\mathrm{P}<0.05)$, regardless the sampling sites. The $\mathrm{S}$ levels in the soils are variable, ranging from less than $<500 \mathrm{mg} \mathrm{kg}^{-1}$ in PM and MONF to approximately $2000 \mathrm{mg} \mathrm{kg}^{-1}$ in CAP and RM. Portuguese cabbage is not very demanding regarding to $\mathrm{pH}$ value, as shows its wide distribution either by inland areas of the country, either by coastal areas, requiring a near-neutral $\mathrm{pH}$, only.

\section{Cabbage}

Portuguese cabbage grows in a wide range of soil and climate conditions, presenting high yield, lower susceptibility to pests and diseases, and generally little or no agrochemical input (Rosa and Heaney, 1996). In this context, the determination of the chemical composition of this crop is a valuable tool to assess its nutritional value. In the current work, calcium, potassium, phosphorus, sulfur, molybdenum and silicon were present in all plant tissues (Table 2) regardless the sampling points, while aluminum failed to be detected in some tissues although presented in roots, always. A similar pattern was observed for $\mathrm{Mn}$ - its presence was only detected in the roots. It must be emphasized the high levels of $\mathrm{Ca}, \mathrm{K}$ and $\mathrm{S}$ in the leaves compared to roots, also $\mathrm{P}$ in a less extent (Table 2), which is probably related with soil characteristics (carbonate and organic matter contents, for example) and possible intensive use of fertilizers containing $\mathrm{K}$ and $\mathrm{P}$, in particular. Calcium in the leaves ranges between $3.3 \%$ and $3.9 \%$, potassium between $2.7 \%$ and $5.3 \%$, while sulfur between $1.3 \%$ and $2.0 \%$. Phosphorus in the cabbage leaves ranges between $0.4 \%$ and $0.8 \%$. The iron content of the leaves is generally poor compared with the root levels, which is probably linked to $\mathrm{pH}$ values of the substrata. The highest Fe concentration $\left(347 \mathrm{mg} \mathrm{kg}^{-1}\right.$ ) was observed in plant leaves collected from CAP site. Selenium, tin, cadmium, mercury and cobalt were never detected in B. oleracea. Regarding those elements beneficial to human health ( $\mathrm{Ca}, \mathrm{P}, \mathrm{K}$ and $\mathrm{Fe}$ ) and considering the cabbage leaves as an important food source, the concentrations found there are well above the requirements established by the U.S. Food and Drug Administration(http:// www.fda.gov/Food/GuidanceRegulation / GuidanceDocuments RegulatoryInformation/

Table 2: Elemental composition (mg. $\left.\mathrm{kg}^{-1}\right)$ of different organs of Brassica oleracea collected in different sampling sites

\begin{tabular}{|c|c|c|c|c|c|}
\hline \multicolumn{6}{|c|}{ Essential Macro and micro elements to Human Health (except Al) } \\
\hline Mineral & Plant organ & CAP & PM & RM & MONF \\
\hline \multirow[t]{3}{*}{$\mathrm{Ca}$} & Root & $30406.5 \pm 277.9 a, s$ & $13311.3 \pm 166.8 \mathrm{c}, \mathrm{s}$ & $16870.2 \pm 226.6 b, s$ & $12270.4 \pm 147.4 \mathrm{~d}, \mathrm{~s}$ \\
\hline & Stem & $18748.4 \pm 237.2 \mathrm{a}, \mathrm{t}$ & $12333.0 \pm 162.4 b, t$ & $12207.4 \pm 158.9 b, t$ & $10515.8 \pm 165.0 \mathrm{c}, \mathrm{t}$ \\
\hline & Leaf & $32685.1 \pm 277.2 \mathrm{c}, \mathrm{r}$ & $39043.2 \pm 310.0 \mathrm{a}, \mathrm{r}$ & $33673.7 \pm 298.0 b, r$ & $33610.8 \pm 265.5 b, r$ \\
\hline \multirow[t]{3}{*}{ K } & Root & $20363.8 \pm 145.8 d, t$ & $33295.4 \pm 191.1 b, s$ & $36656.6 \pm 202.6 \mathrm{a}, \mathrm{t}$ & $25641.6 \pm 210.6 \mathrm{c}, \mathrm{t}$ \\
\hline & Stem & $48859.1 \pm 229.6 \mathrm{~b}, \mathrm{r}$ & $52205.8 \pm 223.2 a, r$ & $48306.2 \pm 231.4 \mathrm{~b}, \mathrm{~s}$ & $32107.7 \pm 195.9 c, r$ \\
\hline & Leaf & $27392.0 \pm 158.9 b, s$ & $52747.4 \pm 235.8 a, r$ & $51696.1 \pm 234.5 a, r$ & $28549.9 \pm 165.2 b, s$ \\
\hline \multirow[t]{3}{*}{$P$} & Root & $3710.8 \pm 110.4 \mathrm{c}, \mathrm{t}$ & $4599.4 \pm 92.0 \mathrm{~b}, \mathrm{~s}$ & $6459.7 \pm 48.5 a, r$ & $3815.1 \pm 86.8 \mathrm{c}, \mathrm{S}$ \\
\hline & Stem & $4268.3 \pm 111.7 \mathrm{c}, \mathrm{s}$ & $4664.5 \pm 89.9 \mathrm{~b}, \mathrm{~s}$ & $2781.4 \pm 25.7 \mathrm{~d}, \mathrm{t}$ & $7811.4 \pm 104.6 \mathrm{a}, \mathrm{r}$ \\
\hline & Leaf & $5141.8 \pm 119.01 b, r$ & $8063.3 \pm 127.1 \mathrm{a}, \mathrm{r}$ & $5052.6 \pm 45.0 \mathrm{~b}, \mathrm{~s}$ & $3807.4 \pm 102.51 \mathrm{c}, \mathrm{s}$ \\
\hline \multirow[t]{3}{*}{$\mathrm{Fe}$} & Root & $3765.7 \pm 39.1 b, r$ & $8874.4 \pm 56.5 a, r$ & $1459.4 \pm 21.8 \mathrm{c}, \mathrm{r}$ & $75.8 \pm 10.1 \mathrm{~d}, \mathrm{~s}$ \\
\hline & Stem & $212.1 \pm 13.1 \mathrm{c}, \mathrm{t}$ & $48.3 \pm 10.4 d, s$ & $462.8 \pm 13.6 b, s$ & $3976.4 \pm 35.1 \mathrm{a}, \mathrm{r}$ \\
\hline & Leaf & $347.0 \pm 14.7 \mathrm{a}, \mathrm{s}$ & $56.6 \pm 10.1 b, s$ & n.d. & $32.9 \pm 9.9 \mathrm{c}, \mathrm{t}$ \\
\hline \multirow[t]{3}{*}{ S } & Root & $8048.5 \pm 84.9 a, t$ & $5524.4 \pm 63.1 \mathrm{c}, \mathrm{t}$ & $5346.1 \pm 128.4 \mathrm{c}, \mathrm{s}$ & $7043.6 \pm 81.0 \mathrm{~b}, \mathrm{~s}$ \\
\hline & Stem & $9772.3 \pm 100.7 a, s$ & $7969.4 \pm 76.9 b, s$ & $4139.5 \pm 116.5 \mathrm{~d}, \mathrm{t}$ & $6587.4 \pm 69.3 c, t$ \\
\hline & Leaf & $14092.6 \pm 118.3 \mathrm{c}, \mathrm{r}$ & 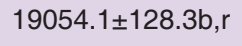 & $12751.8 \pm 167.9 \mathrm{~d}, \mathrm{r}$ & $19811.8 \pm 128.0 a, r$ \\
\hline \multirow[t]{3}{*}{ Mo } & Root & $8.2 \pm 1.1 \mathrm{a}, \mathrm{r}$ & $6.6 \pm 1.0 \mathrm{a}, \mathrm{r}$ & $7.8 \pm 1.0 a, r$ & $9.2 \pm 1.0 \mathrm{a}, \mathrm{r}$ \\
\hline & Stem & $8.3 \pm 1.0 a, r$ & $6.0 \pm 0.9 a, r$ & $8.9 \pm 1.0 a, r$ & $9.7 \pm 0.9 a, r$ \\
\hline & Leaf & $9.4 \pm 1.0 a, r$ & $7.9 \pm 1.0 \mathrm{a}, \mathrm{r}$ & $9.3 \pm 1.0 \mathrm{a}, \mathrm{r}$ & $8.7 \pm 1.0 a, r$ \\
\hline \multirow[t]{3}{*}{$\mathrm{Mn}$} & Root & $36.0 \pm 20.2 a$ & $35.5 \pm 19.1 a$ & $38.2 \pm 15.1 a$ & n.d. \\
\hline & Stem & n.d. & n.d. & n.d. & n.d. \\
\hline & Leaf & n.d. & n.d. & n.d. & n.d. \\
\hline \multirow[t]{3}{*}{ Si } & Root & $75244.7 \pm 433.6 a, r$ & $46967.3 \pm 308.9 b, r$ & $43551.0 \pm 151.8 \mathrm{c}, \mathrm{r}$ & $1290.6 \pm 96.3 d, s$ \\
\hline & Stem & $2458.7 \pm 134.1 \mathrm{~b}, \mathrm{t}$ & $779.4 \pm 91.9 \mathrm{c}, \mathrm{s}$ & $418.3 \pm 27.5 \mathrm{~d}, \mathrm{~s}$ & $22048.4 \pm 236.2 a, r$ \\
\hline & Leaf & $3079.7 \pm 144.7 \mathrm{a}, \mathrm{s}$ & $858.2 \pm 121.4 \mathrm{~b}, \mathrm{~s}$ & $188.8 \pm 57.5 \mathrm{~d}, \mathrm{~s}$ & $555.1 \pm 108.3 \mathrm{c}, \mathrm{s}$ \\
\hline \multirow[t]{3}{*}{ Al } & Root & $3453.2 \pm 238.2 b, r$ & $8182.9 \pm 239.5 a$ & $3206.1 \pm 93.1 b$ & $224.3 \pm 23.7 \mathrm{c}$ \\
\hline & Stem & $371.6 \pm 272.2 b, s$ & n.d. & n.d. & $4412.0 \pm 201.8 a$ \\
\hline & Leaf & $776.0 \pm 255.2 \mathrm{a}, \mathrm{s}$ & n.d. & n.d. & n.d. \\
\hline
\end{tabular}

CAP: Costa da Caparica, PM: Porto de Mós, RM: Rio Maior, MONF: Monforte, n.d.: Not detected; a, b, c, d: - Significant differences ( $p<0.05)$ between sites; $r, s, t$ : - Significant differences $(p<0.05)$ between plant organs. (Mean \pm S.deviation; $n=3$ ) 
LabelingNutrition/ucm064928.htm). The Daily Values (DV) needed, based on a caloric intake of 2,000 calories for adults and children four or more years of age, for $\mathrm{Ca}$, $\mathrm{Fe}, \mathrm{K}$ and P, are: $1000 \mathrm{mg}, 18 \mathrm{mg}, 3500 \mathrm{mg}$ and $1000 \mathrm{mg}$, respectively. As stated above the concentrations of $\mathrm{Fe}$ in the leaves are poor. Also, $\mathrm{Mn}$ was not detected in those organs, while Mo concentrations are near the $9 \mathrm{mg} \mathrm{kg}$ ${ }^{1}$ range. DV required for these metals are $2 \mathrm{mg}$ and 75 $\mathrm{mg}$, for Mn and Mo, respectively. glucosinolates (GLs) are natural S-glucosides, abundant in the family Brassicaceae thus the high levels of sulfur in the leaves are probably related to the aliphatic GLs sources, reported by Vale et al. (2015a, b).

\section{Cabbage interaction with Soil}

Elemental composition of $B$. oleracea vis a vis soil composition (Fig. 2) and bioaccumulation and translocation factors (Table 3) showed distinct patterns according to the different soil composition, the different plant organs and sampling sites. Regarding uptake efficiency $\left(\mathrm{BAF}_{\text {root }}\right.$ $=$ Conc. $_{\text {root }}$ /Conc. ${ }_{\text {soil }}$ ), the Bioaccumulation Factor values are $<1$ for the following elements: $\mathrm{Al}, \mathrm{Fe}, \mathrm{Mn}$ and Si. The $\mathrm{BAF}$ values for $\mathrm{Ca}$ are $<1$ in two cases, with values equal to 0.925 and 0.638 for PM and RM sites, respectively. The BAF values for $\mathrm{K}, \mathrm{Mo}, \mathrm{P}$ and $\mathrm{S}$ are $>1$, with values ranging from $1.34(\mathrm{~K})$ to $16.2(\mathrm{~S})$, in both cases from MONF sampling site (Table 3). The Translocation Factors (from roots to plant leaves) are generally $>1$ in the great majority of the cases, except for $\mathrm{Fe}$ and $\mathrm{Si}$. These findings are probably related with the chemical speciation of soil nutrients and the variable degree of solubility/insolubility of some elements, mainly a function of soil $\mathrm{pH}$. Iron, for example, although abundant in soils is predominantly in the highly insoluble form $\mathrm{Fe}(\mathrm{OH}) 3$ (Reboredo and Ribeiro, 1984), while the solubility of silicic acid is of the order of $100 \mathrm{ppm}$ at near-neutral $\mathrm{pH}$, rising considerably above $\mathrm{pH} 9.0$ due to silicate ion formation (Birchall, 1978). Thus, with the current soil $\mathrm{pH}$ values (between 7.7 and 8.2) the Si uptake is favored compared with the Fe uptake. Furthermore, the availability of the micronutrients, such as $\mathrm{Mn}, \mathrm{Fe}, \mathrm{Cu}$ and $\mathrm{Zn}$, tend to decrease as soil $\mathrm{pH}$ increases. The mechanisms responsible for reducing availability are diverse and might include the formation of low solubility compounds $\mathrm{Fe}(\mathrm{OH})_{3}$, as referred previously, or retention by soil colloids. Despite the Fe levels found in B. oleracea roots the translocation to the above-ground organs was very poor. A similar pattern was observed by in the case of Pennisetum clandestinum (Reboredo et. al., 2006). After entering the epidermis, $\mathrm{Fe}$ is likely bound by unknown chelators or chaperones whose role in the translocation mechanisms are not yet fully understood, although Morrissey and Guerinot (2009), claimed that plants tightly control Fe homeostasis and react to Fe deficiency as well as Fe overload. In conclusion, the relationship between the concentrations of metals in plants and soils can vary greatly according to the plant species and their intrinsic characteristics, soil characteristics, the type of metals, and their speciation (Reboredo, 2012).

\section{Macronutrients}

Protein, total carbohydrates, sucrose, glucose, fructose and raffinose contents in "Tronchuda" leaves, are presented in Table 4. Proteins show significant differences between sites, with CAP having the greatest value and MONF the lowest

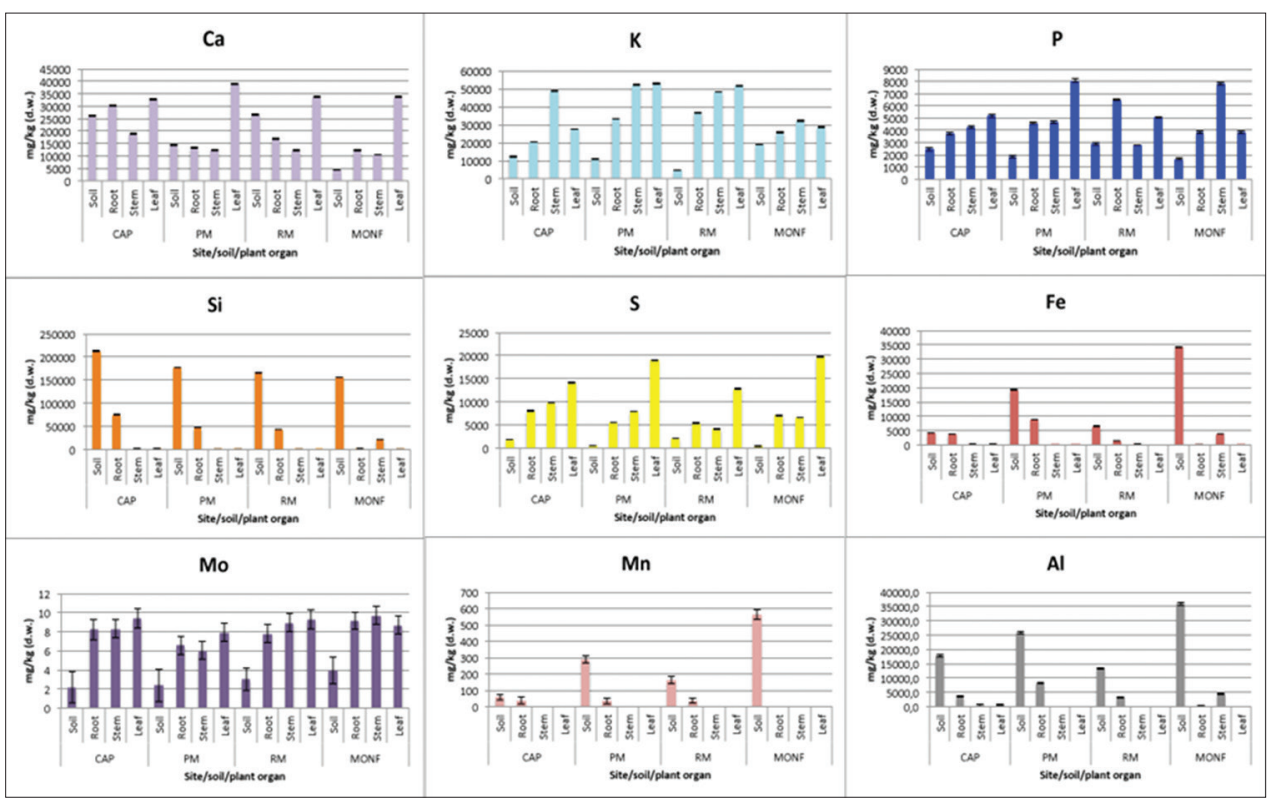

Fig 2. Elemental composition of plant and soil samples in different sampling points (CAP, PM, RM, MONF). Mean values are expressed in $\mathrm{mg} \cdot \mathrm{kg}^{-1} \pm$ S.deviation. 
one. This highest level of protein content in CAP leaves is probably due to the production strategy, as a consequence of use of fertilizers, since these lands are used to produce cabbage and other vegetables to the national market.

Among carbohydrates analyzed, sucrose was the soluble sugar with higher values, whereas raffinose showed the lowest ones. Lower concentrations of raffinose in cabbage leaf are healthier than higher ones, since human organism is unable to synthetize the enzyme capable to hydrolyze raffinose, which therefore remains in the gut, and can promote bad digestion and gas production (Viana et al. 2005). CAP shows the greatest sucrose contents in leaves, contrasting with RM, which showed the lowest value.

The site with the higher contents of total sugars was MONF, and with the lowest was PM, although there were no significant differences between sites. Values showed that these vegetables had little values comparing with fruit or cereals, for instance (Mahan and Krause, 2008).

Table 3: Bioaccumulation factors (BAF) and Translocation Factors in Brassica oleracea collected in different sampling points

\begin{tabular}{|c|c|c|c|c|c|c|c|c|}
\hline \multirow[t]{2}{*}{ Mineral } & \multicolumn{4}{|c|}{ BAF $_{\text {root/soil }}$} & \multicolumn{4}{|c|}{$\mathrm{TF}_{\text {leaf/root }}$} \\
\hline & CAP & PM & RM & MONF & CAP & PM & RM & MONF \\
\hline $\mathrm{Ca}$ & $1.161^{*}$ & $0.925^{\star}$ & $0.638^{*}$ & $2.751^{*}$ & $1.075^{\star}$ & $2.933^{*}$ & $1.996^{*}$ & $2.739^{*}$ \\
\hline K & 1.675 & 3.068 & $7.650^{\star}$ & 1.340 & 1.345 & 1.584 & 1.410 & 1.113 \\
\hline$P$ & $1.533^{*}$ & $2.553^{*}$ & $2.251^{*}$ & $2.272^{*}$ & $1.386^{*}$ & $1.753^{*}$ & $0.782^{*}$ & 0.998 \\
\hline $\mathrm{Fe}$ & 0.895 & $0.461^{*}$ & $0.223^{*}$ & $0.002^{*}$ & $0.092^{*}$ & $0.006^{*}$ & 0.000 & 0.434 \\
\hline S & $4.381^{*}$ & $12.339^{*}$ & $2.603^{*}$ & $16.241^{*}$ & $1.751^{*}$ & $3.449^{*}$ & $2.385^{\star}$ & $2.813^{*}$ \\
\hline Mo & 3.758 & 2.775 & 2.591 & 2.311 & 1.140 & 1.209 & 1.188 & 0.949 \\
\hline $\mathrm{Mn}$ & 0.614 & $0.124^{*}$ & $0.236^{*}$ & $0.000^{*}$ & $0.000^{*}$ & $0.000^{*}$ & $0.000^{*}$ & $\infty$ \\
\hline $\mathrm{Si}$ & $0.353^{*}$ & $0.266^{*}$ & $0.262^{*}$ & $0.008^{*}$ & $0.041^{*}$ & $0.018^{*}$ & $0.004^{*}$ & 0.430 \\
\hline $\mathrm{Al}$ & $0.195^{*}$ & $0.316^{*}$ & $0.239^{*}$ & $0.006^{*}$ & $0.225^{*}$ & $0.000^{*}$ & 0.000 & 0.000 \\
\hline
\end{tabular}

Total fatty acids (TFAs) showed some differences between sampling sites (Table 5), but the values were consistent with previous ones, reported by Scotti-Campos et al. (2011), except for MONF that displayed quite low THA values. Regarding fatty acids profile in cabbage leaves $\mathrm{C}$ 18:3 (linolenic acid) was the highest present and C18:1 (oleic acid) the lowest one. It contains several unsaturated fatty acids, being linolenic (C18:3), linoleic (C18:2) and hexadecatrienoic (C16:3) acid, polyunsaturated, so healthier to human diet than oleic (C18:1) acid (monounsaturated). In fact, all sites produced cabbages with a high percentage of high unsaturated fatty acids (C18:3 and C16:3), ranging between 58\% (MONF) and 65\% (PM) of TFAs. These values are in agreement with those reported earlier for this cabbage (Scotti-Campos et al., 2011), and showed that this cabbage is a rich source of unsaturated Fas for human diet.

\section{CONCLUSIONS}

Portugal global area of farming in 2013 increased in the same rate as in 2012 , being $34.9 \times 10^{3}$ acres $(4.5 \%$ more relative to 2012), with a global production of $900.4 \mathrm{x}$ $10^{3}$ tons (7.1\% more than 2012) (INE, 2014). WHO recommends a $400 \mathrm{~g}$ daily intake of vegetables and fruits, to benefit from their protective effects (OMS, 2003), although the average European daily intake was $220 \mathrm{~g}$ per person (adults) per day.

Regarding uptake efficiency, the Bioaccumulation Factor (Conc. ${ }_{\text {leaf }} /$ Conc. $_{\text {soil }}$ ) values are $<1$ for $\mathrm{Al}, \mathrm{Fe}, \mathrm{Mn}$ and $\mathrm{Si}$ and $>1$ for $\mathrm{K}, \mathrm{Mo}, \mathrm{P}$ and $\mathrm{S}$, regardless the sampling points. The Translocation Factors (from roots to plant leaves) are generally $>1$ in the great majority of the cases, except for $\mathrm{Fe}$ and $\mathrm{Si}$. In this later case, it seems that despite the huge $\mathrm{Si}$ concentrations in the roots the translocation to the above-

Table 4: Protein and carbohydrates ( $\mathrm{mg} \mathrm{g}^{-1} \mathrm{~d} . \mathrm{w}$.) composition of Brassica oleracea leaf according to each site sampled

\begin{tabular}{lccccccc}
\hline Site sampled & $\begin{array}{c}\text { Water } \\
(\%)\end{array}$ & $\begin{array}{c}\text { Protein } \\
\left(\mathbf{m g ~ g}^{-1} \mathbf{d w}\right)\end{array}$ & Saccharose & Glucose & Fructose & Raffinose & Total \\
\hline CAP & 90,44 & $126.3 \mathrm{a}$ & $42.1 \mathrm{a}$ & $4.6 \mathrm{~b}, \mathrm{c}$ & $6.3 \mathrm{~b}$ & $0.5 \mathrm{a}$ & $50.6 \mathrm{a}$ \\
PM & 89,42 & $71.5 \mathrm{a}$ & $8.6 \mathrm{~b}$ & $2.9, \mathrm{c}$ & $6.6 \mathrm{~b}$ & $0.2 \mathrm{a}$ & $18.5 \mathrm{a}$ \\
RM & 89,46 & $63.6 \mathrm{~b}$ & $6.6 \mathrm{~b}$ & $8.1 \mathrm{a}, \mathrm{b}$ & $7.8 \mathrm{a}$ & $0.1 \mathrm{a}$ & $26.0 \mathrm{a}$ \\
MONF & 87,01 & $56.2 \mathrm{~b}$ & $39.1 \mathrm{a}$ & $9.8 \mathrm{a}$ & $13.5 \mathrm{a}$ & $0.0 \mathrm{a}$ & $62.4 \mathrm{a}$ \\
\hline
\end{tabular}

CAP: Costa da Caparica site, PM: Porto de Mós site, RM: Rio Maior site, MONF: Monforte (Portalegre) site; Different letters means significant differences $(p<0.05)$ between sites

Table 5: Fatty acids (mg g ${ }^{-1}$ d.w.) composition of Brassica oleracea leaf of each site sampled $(m e a n \pm S D ; n=3)$

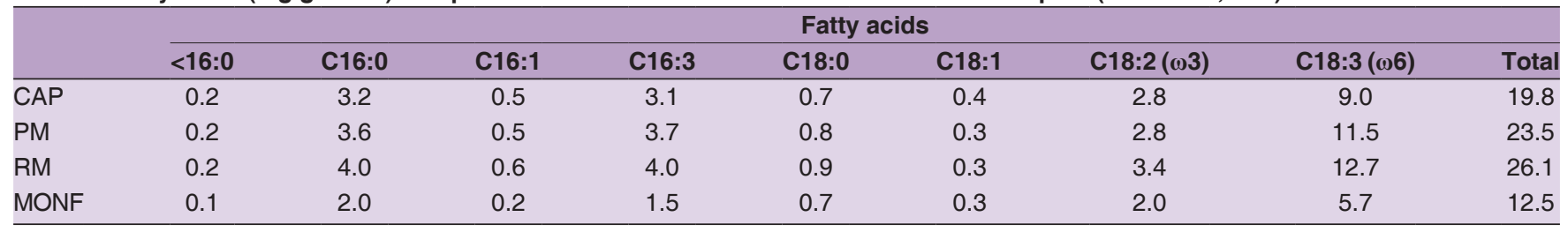

CAP: Costa da Caparica site, PM: Porto de Mós site, RM: Rio Maior site, MONF: Monforte (Portalegre) site; <16:0 - Saturated acids; C16:0 - Palmitic acid; C16:1 - Palmitoleic acid; C16:3 - Hexadecatrienoic acid; C18:0 - Estearic acid; C18:1 - Oleic acid; C18:2 - Linoleic acid ( $\omega 3$ ); C18:3 - Linolenic acid ( $\omega 6)$ 
ground organs is poor. Also, is poor the translocation of Fe to the leaves, although great differences were observed between $\mathrm{Fe}$ and Si pools in the substrata. While Si levels in the roots were clearly higher than the levels observed in the soil, conversely, the Fe levels in the roots were clearly lower. Taking into account the Daily Values (DV) required for human consumption, the concentrations are generally adequate although the levels of $\mathrm{Fe}$ in the leaves were scarce, while the levels of Ca were abundant $(>3 \%$, always), although in agreement with the data of Rosa and Heaney (1996) who found an average concentration of $\mathrm{Ca}$ of $34.4 \mathrm{~g} \mathrm{~kg}^{-1} \mathrm{dry}$ weight, in the leaves. Manganese levels were only detected in the cabbage roots. In this particular case, the element must be obtained in other foodstuffs. In conclusion, all sites may produce in a safety manner Portuguese cabbages (heavy metals such as, $\mathrm{Cd}, \mathrm{Hg}, \mathrm{Ni}$, Sn were never detected), although soils from CAP showed a soil nutrient exhaustion ( $\mathrm{Fe}, \mathrm{Mn}$ and $\mathrm{Mo}$ ) due to the continuous crop cultivation throughout decades.

\section{Author's contributions}

M. F. Pessoa, M. Simões, A. Feteiro and D. Canuto designed the study and selected and collected the samples. M. F. Pessoa, J. Pelica, A. Feteiro, D. Canuto and I. Pataco were responsible for mineral analysis; P. Scotti-Campos and I. Pais were responsible for macronutrient analysis. All authors were involved in the writing and critical review of the article.

\section{REFERENCES}

Allen, C. F., P. Good, H. S. Davis, P. Chisum and S. D. Fowler. 1966. Methodology for the separation of plant lipids and application to spinach leaf and chloroplast lammelar. J. Am. Oil Chem. Soc. 43: 223-230.

Ayaz, F. A., S. Hayirhoglu-Ayaz, S. Alpay-Karaoglu, J. Grúz, K. Valentová, J. Ulrichová and M. Strnad. 2008. Phenolic acid contents of kale (Brassica oleracea L. var. acephala DC.) Extracts and their antioxidant and antibacterial activities. Food Chem. 107: 19-25.

Batista, C., L. Barros, A. M. Carvalho and I. C. F. Ferreira. 2011. Nutritional and nutraceutical potential of rape (Brassica napus L. var. napus) and "tronchuda" cabbage (Brassica oleraceae L. var. costata) inflorescences. Food Chem. Toxicol. 49: 1208-1214.

Birchall, J. D. 1978. Silicon in the biosphere. In: Williams, R. J. P. and J. J. R. da Silva, editors. New Trends in Bio-inorganic Chemistry. Academic Press, London, p. 489.

Ferreres, F., C. Sousa, V. Vrchovská, P. Valentão, J. A. Pereira, R. M. Seabra and P. B. Andrade. 2006. Chemical composition and antioxidant activity of tronchuda cabbage internal leaves. Eur. Food Res. Technol. 222: 88-98.

Ferreres, F., C. Sousa, P. Valentão, R. M. Seabra, J. A. Pereira, and P. B. Andrade. 2007. Tronchuda cabbage (Brassica oleracea L. var. costata DC) seeds: Phytochemical characterization and antioxidant potential. Food Chem. 101: 549-558.

Gornall, A. G., C. J. Bardawill and M. M. David. 1949. Determination of serum proteins by means of the biuret reaction. J. Biol. Chem. 177: 751-766.

INE. 2014. Estatísticas Agrícolas 2013. INE, Lisbon, p. 19.

INSA. 2007. Tabela da Composição de Alimentos. Ministério da Saúde, Lisboa: Instituto Nacional de Saúde Dr. Ricardo Jorge.

Jahangir, M., I. B. Abbel-Farid, H. K. Kim, Y. H. Choi and R. Verpoorte. 2009. Healthy and unhealthy plants: The effect of stress on the metabolism of Brassicaceae. Environ. Exp. Bot. 67: 23-33.

Mahan, L. and S. Krause. 2008. Alimentos, Nutrição e Dietoterapia, $12^{\text {nd }}$ ed. St. Paulo: Roca.

Medlicott, A. P. and A. K. Thompson. 1985. Analysis of sugars and organic acids in ripening mango fruits (Mangifera indica L. var. Keitt) by high performance liquid chromatography. J. Sci. Food Agric. 36: 561-566.

Morrissey, J. and M. L. Guerinot. 2009. Iron uptake and transport in plants: The good, the bad, and the ionome. Chem. Rev. 109: 4553-4567.

OMAIAA - Observatório dos Mercados Agrícolas e das Importações Agro-Alimentares/Observatory of Agricultural Markets and Agro-Food Imports. 2011. O Mercado Português das Couves. Available from: http://www.observatorioagricola.pt/item.asp?id_ item $=128$. [Last accessed on 2015 Oct 26].

Ramalho, J. C., Z. S. Zlatev, A. E. Leitão, I. P. Pais, A. Fortunato and F. C. Lidon. 2014. Moderate water stress causes differential stomatal and non-stomatal changes on the photosynthetic functioning of Phaseolus vulgaris L. genotypes. Plant Biol. 16: 133-146.

Reboredo F. H. S. and C. A. G. Ribeiro. 1984. Vertical distribution of $\mathrm{Al}, \mathrm{Cu}, \mathrm{Fe}$ and $\mathrm{Zn}$ in the soil salt marshes of the Sado estuary, Portugal. Int. J. Environ. Stud. 23: 249-253.

Reboredo, F., R. Bragadesto and L. Sousa. 2006. Do silicon levels in the matrix influence the mineral nutrition of Pennisetum clandestinum (Hochst. ex Chiov)? Arch. Agron. Soil Sci. 52: 353-358.

Reboredo, F. 2012. Zinc compartmentation in Halimione portulacoides (L.) Aellen and some effects on leaf ultrastructure. Environ. Sci. Pollut. Res. 19: 2644-2657.

Rosa, E. and R. Heaney. 1996. Seasonal variation in protein, mineral and glucosinolate composition of Portuguese cabbages and kale. Anim. Feed Sci. Technol. 57: 111-127.

Scotti-Campos, P., J. N. Semedo, I. P. Pais, M. Oliveira, M. Passarinho and J. C. Ramalho. 2014. Heat tolerance evaluation of Portuguese old bread wheat varieties. Emirates J. Food Agric. 26: 170-179.

Scotti-Campos, P., I. P. Pais, J. N. Semedo, P. R. Ramos, C. S. Santiago, P. S. Coelho, L. P. Valério and A. A. Monteiro. 2011. Membrane lipid composition in Brassica oleracea plantswith different resistance to downy mildew. Acta Hortic. 917: 159-166.

Sousa, C., M. Taveira, P. Valentão, F. Fernandes, J. A. Pereira, L. Estevinho, A. Bento, F. Ferreres, R. M. Seabra and P. B. Andrade. 2008. Inflorescences of Brassicaceae species as source of bioactive compounds: Comparative study. Food Chem. 110: 953-961.

Sousa, C., H. Pontes, H. Carmo, R. J. Dinis-Oliveira, P. Valentão, P. B. Andrade, F. Remião, M. L. Bastos and F. Carvalho. 2009. Water extracts of Brassica oleracea var. costata potentiate paraquat toxicity to rat hepatocytes in vitro. Toxicol. In Vitro. 23: 1131-1138.

Vale, A. P., J. Santos, N. V. Brito, D. Fernandes, E. Rosa and M. B. P. Oliveira. 2015a. Evaluating the impact of sprouting conditions on the glucosinolate content of Brassica oleracea sprouts. Phytochemistry. 115: 252-260.

Vale, A. P., J. Santos, N. V. Brito, V. Peixoto, R. Carvalho, E. Rosa 
and M. B. P. P. Oliveira. 2015b. Light influence in the nutritional composition of Brassica oleracea sprouts. Food Chem. 178: 292-300.

Vaughan, J. G. and C. A. Geissler. 1997. The New Oxford Book of Food Plants. Oxford University Press, New York, Pp. 166-169.

Viana, S., V. Guimarães, I. José and M. Oliveira. 2005. Hydrolysis of oligosaccharides in soybean flour by soybean a - Galactosidase. Food Chem. 93: 665-670.
Vrchovská, V., C. Sousa, P. Valentão, F. Ferreres, J. A. Pereira R. M. Seabra and P. B. Andrade. 2006. Antioxidative properties of tronchuda cabbage (Brassica oleracea L. var. costata DC) external leaves against DPPH, superoxide radical, hydroxyl radical and hypochlorous acid. Food Chem. 98: 416-425.

WHO. 2003. Promoting fruit and vegetable consumption around the world. Available from: http://www.who.int/dietphysicalactivity/ fruit/en/. [Last accessed on 2015 Nov 04]. 